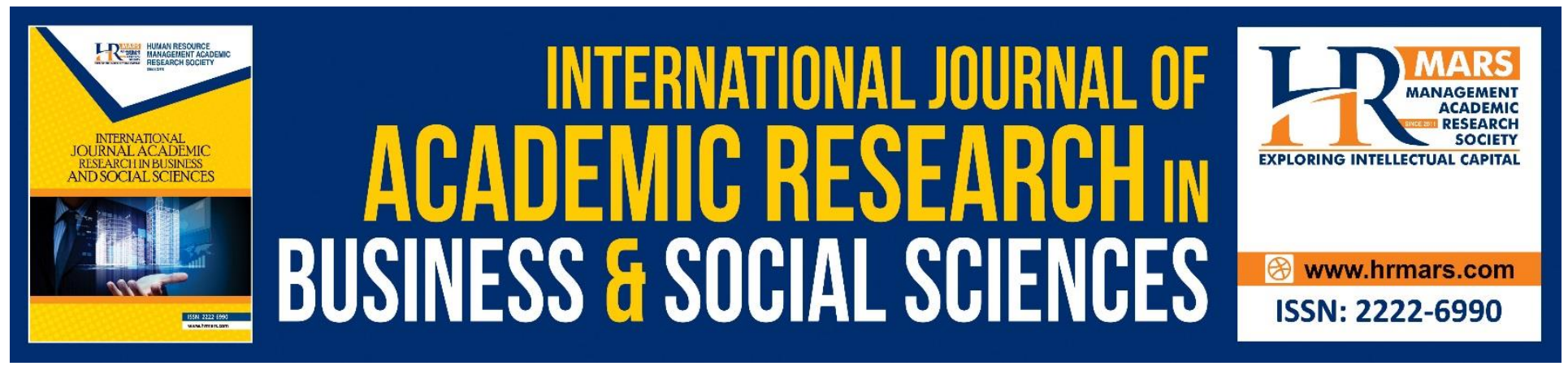

\title{
Implications of Boko Haram Insurgency on Integration: Evidences from Northern Nigeria
}

\author{
Anthony Abah Ebonyi
}

To Link this Article: http://dx.doi.org/10.6007/IJARBSS/v9-i2/5591

DOI: $\quad 10.6007 /$ IJARBSS/v9-i2/5591

Received: 08 Feb 2019, Revised: 25 Feb 2019, Accepted: 12 March 2019

Published Online: 14 March 2019

In-Text Citation: (Ebonyi, 2019)

To Cite this Article: Ebonyi, A. A. (2019). Implications of Boko Haram Insurgency on Integration: Evidences from Northern Nigeria. International Journal of Academic Research in Business and Social Sciences, 9(2), 554-567.

\section{Copyright: (C) 2019 The Author(s)}

Published by Human Resource Management Academic Research Society (www.hrmars.com)

This article is published under the Creative Commons Attribution (CC BY 4.0) license. Anyone may reproduce, distribute, translate and create derivative works of this article (for both commercial and non-commercial purposes), subject to full attribution to the original publication and authors. The full terms of this license may be seen at: http://creativecommons.org/licences/by/4.0/legalcode

Vol. 9, No. 2, 2019, Pg. 554 - 567

Full Terms \& Conditions of access and use can be found at http://hrmars.com/index.php/pages/detail/publication-ethics 


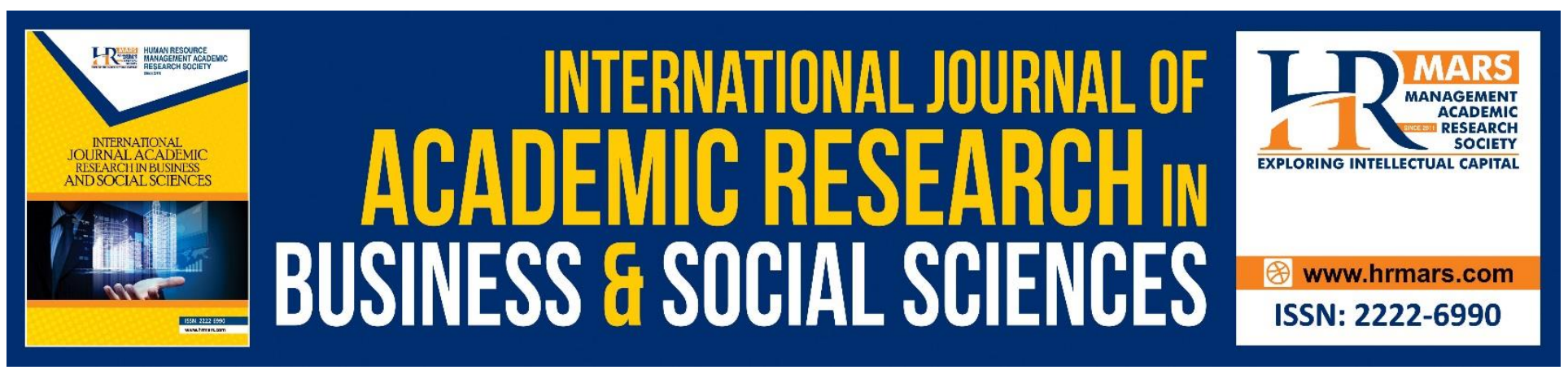

\title{
Implications of Boko Haram Insurgency on Integration: Evidences from Northern Nigeria
}

\author{
Anthony Abah Ebonyi \\ Department of Sociology, Faculty of Social Science, APIS - University of Abuja, Abuja, Nigeria \\ Email: ebonyiaab@gmail.com
}

\begin{abstract}
The paper investigated the implications of Boko Haram Insurgency on integration in the northern states of Nigeria. It utilized secondary data sourced from books, research journals, reports, magazines, newspapers, and thesis to trace the evolution of Boko Haram insurgence and its implications for integration. The study was anchored on the Relative Deprivation Theory to argue that the inability of the people especially the youth, to benefit from resource allocation, was a factor in the emergence of Boko Haram insurgency. It utilised the qualitative method of content analysis to discuss secondary data sourced online. It found that several factors precipitated the Boko Haram insurgency, such as poverty, unemployment, etc., resulting in social, economic and political consequences; and the federal government responded to the insurgency using soft and hard measures. This paper concluded that while the sect's mission to institute a strict version of Islam and introduce sharia law across Nigeria, especially in the north, has failed, it has succeeded in disintegrating the southerners and the northerners who hitherto had lived together in peace and harmony. The paper recommends that the government could still adopt the soft approach for dialogue with the insurgents by granting amnesty to the repentant members of the sect, provide employment, and allow the uneducated or illiterates amongst them to either go to school or to acquire skills for self-employment as part of short run measures. Needless to say that long or longer term measures have to be put in place to concretely and holistically resolve the insurgency in hope that peace might return to the volatile northeast in particular and northern Nigeria generally.
\end{abstract}

Keywords: Boko Haram, Insurgency, Integration, Northeast, Northern Nigeria

\section{Introduction}

Nigeria, before the emergence of the Boko sect, was hitherto inundated with various security challenges arising from the activities of sectarian groups. These groups include major ones like the Niger Delta Militants (under different names); the Odua People's Congress (OPC); the Movement for Actualization of Sovereign State of Biafra (MASSOB), Maitatseni, etc. However, the Boko Haram insurgency has unsettled the Nigerian State more than all the others combined in terms of loss of 
lives and properties as argued by different scholars (Solomon, 2012; Aro, 2013; Oladesu, 2013;Dauda, 2014; Barna, 2014). Not even the Nigerian Civil War of 1967-1970 which claimed more than one million lives could be compared to the Boko Haram's atrocious actions (Solomon, 2012). The crisis has also resulted in the displacement of persons as refugees scattered across northern Nigeria, and recorded thousands of deaths (Barna, 2014).

The activities of the Boko Haram group have not only heightened insecurity in the affected northeast region from where it started, but also the entire northern states of Nigeria. The Northern states have become like a pariah region of the country, where people now fear to travel to, live, school, do business, and even inter-marry. For example, parents now shudder at the thought of sending their wards to the Northern Schools, particularly the higher institutions to study. Those who graduated from the higher institutions, when it comes time for the National Service, most of them rather abandon their posting than risk being killed serving in the north. In the event that a Corp member was posted to the north, he or she would virtually plead with their parents, uncle or other relatives, to help facilitate their re-posting to a non- northern state for the mandatory service, where they felt their lives would be secure. The Boko Haram insurgency also impacts on commerce, banking and finance. For instance Dauda (2014) argued that, because of the decisions by banks to reduce their hours of operation to safeguard their business premises, customers who comprised mainly traders, were unable to deposit daily proceeds in the banks. These traders, having no other option, had to hide their monies in their shops; which consequently got stolen by burglars.

Since the emergence of Boko Haram (particularly from 2009 till date) in North-Eastern Nigeria, it has claimed about 100,000 lives and displaced 2,114,000 persons (Tukur, 2017). The Federal Government's efforts to curb the Boko Haram insurgency has yielded very little results because the group still carries out sporadic attacks on innocent people in their characteristic suicide bombing style, a situation which according to Moahmmed Kyari, made "our lives abnormal" (cited in Quartz Africa, 2015).

The objectives of this paper is to investigate the emergency of Boko Haram in the northeast; the factors that led to it, and the over-arching implications on integration in the entire northern states of Nigeria. This becomes imperative owing to the unpleasant experiences of people living in the area as well as outsiders or rather people who have had to engage in one form of activity or the other with the northeasterners. The analysis revealed that poverty, unemployment, and frustration of the northeasterners propelled young people to join Boko Haram and thus, enlarge its membership and gave the group courage to continue to unleash mayhem on hapless people.

\section{Objectives of the Study}

This study analyses the implications of Boko Haram insurgency for integration. The specific objectives of the study include:

i. To determine the factors that led to the emergence of Boko Haram in the northeast.

ii. To examine the implications of the insurgency on integration in the northern parts of the country.

iii. To explore what can be done as an alternative to the current military tactics, to curb the Boko Haram insurgency and to re-integrate people in northern Nigeria. 


\section{Literature Review}

Academics have analysed the activities of the Boko Haram sect since it emerged in northeastern Nigeria, and the security implications of same on different planks such as social, economic, and political. Less broadly studied is the extent to which the group's actions in the northeast have impacted on security of lives and property but particularly on integration of people from the north and the south of Nigeria. Thus, this study is significant in that it will bring to limelight the negative impact of the Boko Haram insurgency, and as it affects particularly the integration of people in northern Nigeria, who have always, lived together, transacted business together, intermarried, among others.

Eme and Ibietan (cited in Owojobi, 2014) in their analysis of the origin and ideology of the sect, argued that Boko Haram otherwise known as Jama'atu Ahlis Sunna Lidda'awatiWal-Jihad was an Islamic terrorist group with a strong operational base in northeastern Nigeria. Eme and Ibietan (cited in Owojobi, 2014) surmised that the ideology of Boko Haram was to dismantle the secular structure of government in Nigeria and replace it with an Islamic system that was founded on sharia law. However, Lister (cited in Owojobi, 2014) held a contrary view to Eme and Ibietan that Boko Haram sought to Islamize Nigeria by introducing sharia law. Instead he opined that Northern politicians, who were bent on fomenting disunity in the country based on their selfish goals, had employed the services of disgruntled youths who were foot soldiers of the sect and paid them to perpetrate callous crimes in Nigeria

Aro (2013) observed that Boko Haram had in the cause of their campaign of terror, perpetrated heinous atrocities in Nigeria more than the other insurgent or militant groups that had emerged in the country. Oladesu (cited in Aro, 2013) shared a similar view when he stated that since after the horror of the civil war, none again had been seen as the one unleashed by the dreadful Boko Haram sect; in which many lives and properties totaling millions of naira had been destroyed. Also, a report indicated that the insurgency has displaced about three million to five million people, as well as truncated trade networks around Maiduguri, Kano, and Mubi, in addition to preventing several communities from farming (Quartz Africa, 2015).

Dauda (2014) has analyzed in details some of the security implication of the Boko Haram insurgency. They included dwindling economic activities involving banking, trade and commerce. For instance, he observed that in the heyday of the insurgency in Yobe State, commercial banks that previously went to the rural or local government areas to pay staff salaries, had to stop for fear of being attacked by Boko Haram insurgents. This according to him put the lives of the local government employees in danger. The situation in Yobe State had a ripple effect in the north in such States as Kano, which former Minister of Information, Mr. Labaran Maku, had referred to as ". . the economy of Chad, ... the economy of Niger Republic, and of northern Cameroun." Hence, he added ". . when you destabilize peace in Kano, you threaten the foundation of economic and social well-being of that region" (cited in Dauda, 2014); thus leading to the general disintegration of the people of Northern Nigeria. 


\section{Theoretical Framework}

This paper adopted Relative Deprivation theory as basis for understanding and explaining the implications for security and integration of the Boko Haram insurgency in northern Nigeria. In his reformulation of relative deprivation theory, Gurr argued that people experience dissatisfaction arising from their perceived feeling of lack, that is, if the feel short-changed by their society or benefactor. In the long run, their pint-up dissatisfaction gravitates towards frustration subsequently leading to rebellion against the real or perceived source of their deprivation (Agbiboa, 2013). Hence, Gurr defined relative deprivation as an "actor's perception of discrepancy between their value expectations and their value capabilities" (as cited in De Silva, n.d). Gurr further averred that structural poverty and inequality within a given country are "breeding grounds for violent political movements in general and terrorism specifically" (cited in Agbiboa, 2013).

It can be gleaned from the above postulations that most of the insurgencies (except perhaps, the Maitatsine uprising of 1980s) that have arisen since independence in 1960 in Nigeria, were as a result of one group or the other feeling that its chances of enjoying the social and economic blessings of the land have been blocked by the Nigerian society. They felt they were deprived of their legitimate rights to survival and self-actualization and left to wallow in poverty. Research has shown that, the worst form of insurgency in Nigeria's post-independence history was birthed in northern Nigeria, the most socioeconomically deprived region of the country after the Niger Delta, with very high poverty level and unemployment rate. For instance, the 2010 poverty profile by the National Bureau of Statistics (NBS) indicated that the North-East and North-West geo-political zones, recorded the highest poverty rates of 64.8 percent and 61.2 percent, respectively compared to the lowest rates of 31.2 percent and 40.2 percent in the South-East and South-West regions, respectively (National Bureau of Statistics [NBS], 2012). According to Agbiboa (2013), their report was supported by United Nations Development Programme (UNDP) report of 2009, which showed that the top five poorest states in the poverty index in Nigeria were all in the north. The Boko insurgency in the north-east, and the downward spiral effects in the whole of the northern states of Nigeria in terms of security and integration, is tied to the dissatisfaction and eventual frustration felt by the poor, unemployed and socially and economically disadvantaged youth population in the region over the cause of time.

\section{Research Method}

The qualitative method was adopted for data collection for this study and to achieve its set objectives. Qualitative research method seeks to present results in words rather than statistics, and which analysis is based on lived social realities and experiences (Othman, M. F., Sule, I. Z. O. and Singh, R. S2015). Content analysis was the approach employed to explain the data collected. The method was adopted to gain a broad insight into how the activities of the Boko Haram sect have impacted on the people's livelihoods and integration in northern Nigeria. This study collected secondary data from government publications, International agencies reports; various scholarly journal articles; public records and statistics, speeches by various individuals, etc, which were employed for the analysis. 


\section{Evolution of Boko Haram Insurgency in the North-East}

The northeast is one of the geo-political zones in Nigeria. It comprises the following states: Adamawa, Bauchi, Borno, Gombe, Taraba, and Yobe. The Northeast region has an estimated population of 22.3 million people. 173 are predominantly Muslim, 175 belong to the Hausa-Fulani and Kanuri ethnic groups, who are said to constitute approximately $29 \%$ and $4 \%$, respectively of the country's population (AOAV \& NWGAV, 2013). The figure below is a map showing the Northeastern States of Nigeria.

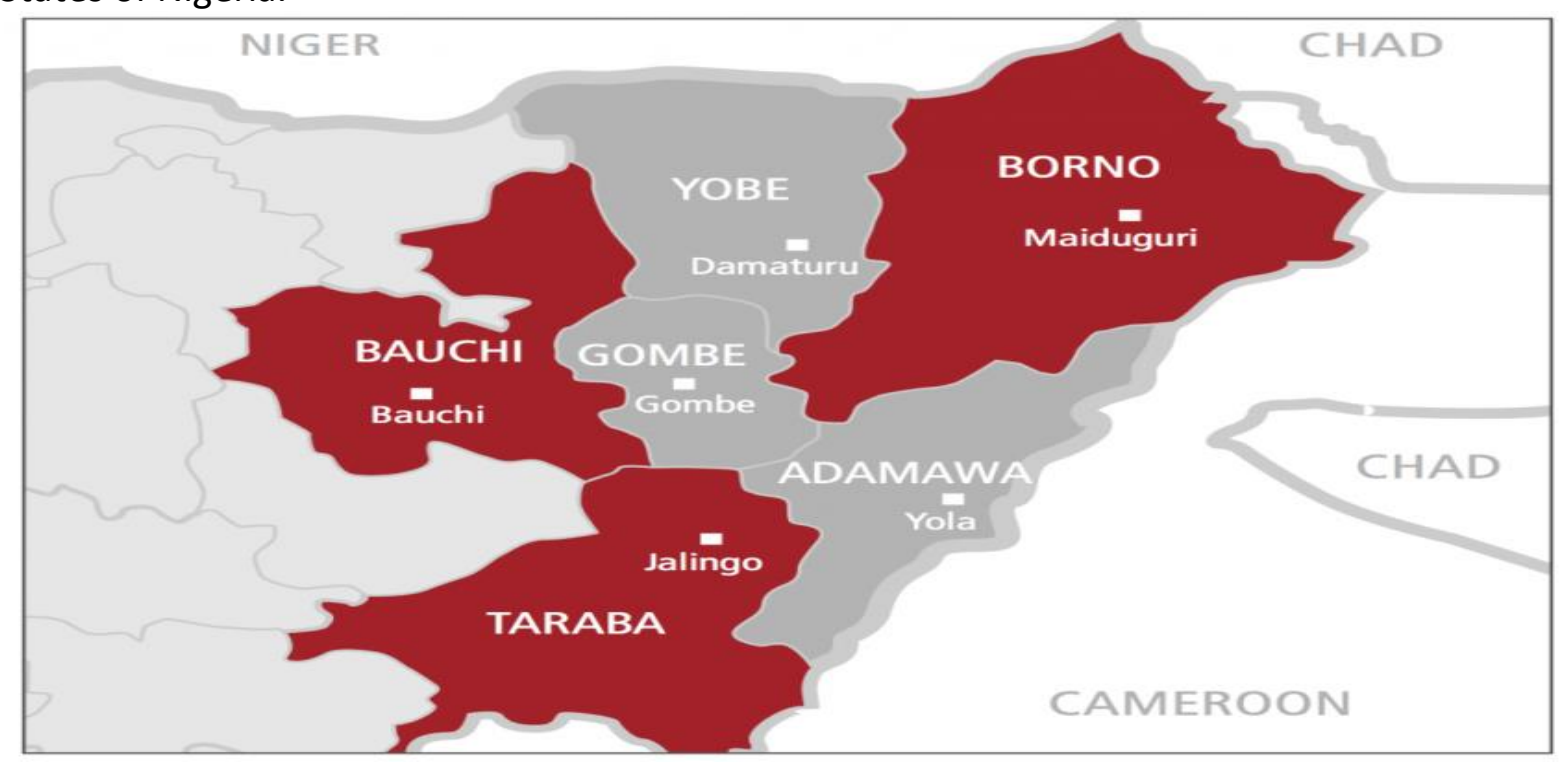

Source: National Working Group on Armed Violence \& Action on Armed Violence (AOAV \& NWGAV) - Violent Road: Nigeria's North East. Available at https://aoav.org.uk/2013/the-violent-road-nigerianorth-east/

Boko Haram is officially known by its founders as Jama'atuAhlis Sunna Lidda'awatiWal-Jihad, translated as "people committed to the propagation of the Prophet's teaching and Jihad". It is a religious sect with footholds in mostly north-eastern regions of Nigeria, but which has since becoming violent, spilled-over to Cameroon, Chad and Niger (Council of Foreign Relations, cited in Vybiralova, 2016). The origins of Boko Haram are traceable to three different but related historical periods; the first was a group of radical Islamist youth who worshipped at the Alhaji Muhammadu Ndimi Mosque in Maiduguri in 2002. In that year, an offshoot of this youth group, before it was known as Boko Haram, deemed the city and the Islamic establishment to be grossly corrupt beyond salvation. Thus, to extricate itself from this corrupt brand of Islam, it declared hijra, in conformity with the Prophet Muhammad's withdrawal from Mecca to Medina, and relocated to the village of Kanama, in Yobe State, along the Nigeria-Niger border. There, the group formed a separatist community based on strict Islamic principles. Under its leadership, Mohammed Ali, the group promoted anti-state ideology and urged other Muslims to join its rank and return to the true Islam, which aimed to have a more perfect society devoid of corruption. The group had a community dispute in December, 2003, over fishing rights in a local pond, which later resulted in conflict with the Police. The Police officers were overpowered and their weapons seized in the conflict. The Army was drafted in and had a gun battle 
with the insurgents at their Mosque, which ended in the group losing about seventy of its members, including their leader, Mohammed Ali.

The second period was a similar scenario that played out much later in Maiduguri, in 2009 under a new leader, Mohammed Yusuf. He too, like the predecessor, established a mosque in Maiduguri which he named Ibn Taimiyyah Masjid. It was during this time that the group got its current name Boko Haram", given to it by its neighbours in Maiduguri. Boko Haram simply translates as "Western Education is forbidden" in Hausa. According to observers, the group operated a "state within a state," including a cabinet, religious police, and a large farm. It attracted followership comprising refugees and jobless Nigerian youths, by offering welfare handouts, food, and shelter (the very basic necessities that they were deprived of by their society or the government) (Walker, 2012).

Under the third period, a new leadership of the Boko Haram sect emerged after the demise of Mohammed Yusuf in 2009, when he was killed in a clash with security agencies in Maiduguri, in which his uncle also died. Under the new and still surviving leader, Abubakar Shekau, the group has become violent engaging in all sorts of terrorist actions ranging from suicide bombing, kidnapping, robbery, etc, all in the bid to instill fear in the general population and cause the federal government to accede to its demands of establishing a strict version of Islam guided by Islamic sharia law. According to Kyari Mohammed, when Boko Haram's re-emergence from 2009, it changed its tactics to "targeted assassinations, drive-by shootings, suicide bombings, and massive deployment of improvised explosive devices (IEDs), vehicle-borne IEDs, and, lately, kidnapping and hostage taking" (Mohammed, 2014). It is worth noting that the current group has ties with such terrorist groups as Al-Qaeda in the Islamic Maghreb (AQIM), and also pledged allegiance to the Islamic State (IS); even though this narrative is controversial and is still being investigated (Adibe, 2013; Vybiralova, 2016).

\section{Factors that led to the Emergence of Boko Haram Insurgency in the North-East}

Several factors led to the emergence of Boko Haram in the northeast. These factors are synonymous with those that trigger its spread to the entire northern states, thereby posing enormous security challenges and threatening the unity of Nigeria. The headings employed to analyze the factors that triggered Boko Haram's emergence in Northeastern Nigeria were drawn from the work of Akinbi (2015).

\section{Rejection of Western Education and Value}

Boko Haram emerged on the wings of the declaration of the rejection of secularism, democracy, Western education, and Westernisation by its founders; and its replacement by shariah (Mohammed, 2014). The name "Boko Haram" denotes "Western Education is forbidden". From this it becomes obvious that the group would have nothing to do with Western valueincluding education, fashion, music, religion, and sundry others. For example, based on the notion that Western education is valueless, prospective educated members of the sect, before admittance into the group have had to tear their certificates furtherance of their acceptance of the ideology of Boko Haram. Some scholars (Danjibo, n.d; Teshome, 2008, and Ucha, 2010, cited in Agegba, 2015) have argued that the young people who tore their certificates out of frustration did so to demonstrate their loyalty to the sect and to embrace the sect's teaching that "Western education is forbidden". For example Danjibo (n.d) stated that: 
One can imagine the frustration for a young man or woman who had graduated from the University and could secure job years after graduation. For such a person, Western education will ever remain valueless. As a matter fact, such youths live in a country where education is treated with much disdain and where the educated are insignificant, but where uneducated political bandits are assigned status privilege. (cited in Ayegba, 2015)

Ayegba concluded that the views expressed above might explain why many northern Nigeria youths join terrorist groups such as Boko Haram.

\section{Religious Bigotry and Imposition of its Ideals}

Nigeria being a secular State, allows for freedom of religion. This is clearly enunciated in the Constitution of the Federal Republic of Nigeria 1999 (as amended), particularly in Section 38 (1). It means, therefore, that no single religion in Nigeria is superior to the other which might warrant its values or doctrines being forced upon any individual or group whatsoever. In a study conducted by Yahaya (cited in Ebonyi, 2018), it was discovered that wrong perception, orientation, interpretation and selfishness on the part of religious leaders and their adherents could precipitate religious conflict Similarly, the Boko Haram insurgency arose from a situation of wrong perception and interpretation of Islam and the sect's selfish and forceful imposition of their version of Islam on ignorant youths in the North-East. On one occasion, Mohammed Yusuf, the demised leader of Boko Haram, delivered a sermon to his followers saying:

In this dawah we agreed that we are going to suffer like Bilal was dragged on the ground, just like Ammar Ibn Yasir was tortured, just like a spear was thrust unto Summayyah's vagina. These are trials we are awaiting ... These are the hurdles we want to cross. Anyone who dies in the process goes to Paradise. This is our dawa. (Mohammed, 2014, p. 15)

His gullible followers bought into this sermon and subsequent ones, thus, fueling their resolve to perpetrate mayhem on hapless northeasterners and many other people across the northern parts of Nigeria.

\section{Poverty, unemployment and Ignorance}

The narrative that poverty and unemployment ignorance or illiteracy (Harnischfeger, 2014, Akinbi, 2015), precipitate Boko Haram insurgency features in almost all literature on conflict. While some scholars have argued that poverty and unemployment is to blame for the myriads of insurgencies across the globe, in the case of Nigeria, the insurgency of the Boko Haram was said to have been caused not directly by poverty but by failure of governance. Agbiboa lent his voice to the debate when he stated that a closer look at Boko Haram rhetoric revealed that poverty is linked to governmental corruption and mismanagement which serve to illegitimate a government, as against the actual structural imbalance Boko Haram sets out to correct.

Furthermore, a glimpse into the membership of Boko Haram showed that both the poor and the affluent or elites join its ranks for economic and social gains. However, the controversy persisted 
with others arguing that Boko Haram membership comprises "poor, uneducated, unemployed and illegals" (Vybiralova, 2016). As demonstrated by the relative deprivation theory above, when people perceive themselves as being worse off than others (politically or economically) in a society that promises to provide for them, conflict sets in as reaction to the "intolerable gap" between expected satisfaction and actual satisfaction in the course of time. In the opinion of one analyst, "young militants in Maiduguri or Kano have good reasons to hate the representatives of the state. Their rebellion is born out of poverty, illiteracy, and unemployment; it is a response to corruption and social neglect" (Harnischfeger, 2014). As seen from the arguments above, politically excluded groups, economically unequal groups are more likely to rebel, as demonstrated by the Boko Haram group.

The assertion by some analysts including Akinbi (2015) that unemployment was to blame for the emergence of Boko Haram in the north-east seem to have been contradicted by the admonition of Mohammed Yusuf to his members that their religious belief abhors working in a government that was anti-shariah, and so serving under it was illegitimate. As a matter of fact while referring to his group he asserted "our call refuses employment under the government which does not rule by what Allah has revealed such as the French law, the American law, the British law or any other constitution or system that goes against the teachings of Islam and negates the Qur'an and Sunnah" (Mohammed, 2014, p. 16). It is recalled that the rejection of Western education and Westernisation formed the twin pillars of the Jama'atuAhlis Sunna Lidda'awatiWal-Jihad.

\section{Implications of Boko Haram Insurgency on Integration in Northern Nigeria}

Numerous scholars including Agbiboa (2013) have attested to the implications of the Boko Haram Insurgency for Northern Nigeria in terms of security and integration. According to him, the effects have been far-reaching and alarming. In one study it was found that the effect of poverty on health and education in Borno State was frighteningly high. For example, the Oxford Research Group in 2012 discovered that "only $2 \%$ of children under 25 months have vaccinated; $83 \%$ of young people are illiterate; $48.5 \%$ of children do not go to school." Similarly, the National Population Commission reported that literacy rates are lower in the northern states; adding that 72 percent of children between the ages of 6-16 never attended schools in Borno State (Agbiboa, 2013).

Awojobi (2014) argued that apart from the loss in human lives occasioned by the Boko Haram insurgency, the economic, social and psychological costs of same were unquantifiable. This could be seen in the reduction in commercial activities in the northeast in the areas of banking and finance. Citing other scholars (Okereocha, 2012; Shiklam; 2012, and Mohammed, 2012), Awojobi noted that socio-economic activities were adversely undermined because of the incessant attacks. It had drained human capital and investment which have hindered economic development in the northeast. As a consequence also, people (especially none northerners) have migrated to other more secured parts of the country. For example Shiklam (cited in Awojobi, 2014) observed that "The Maiduguri Monday Market said to be the biggest in the city is reported to have been seriously affected as hundreds of shop owners, especially Southerners are said to have closed their business and left the troubled city. About half of the 10,000 shops and stalls in the market were said to have been abandoned by traders who have fled the city". The long term implications of the insecurity situation, as earlier predicted by the BusinessDay Newspaper, would be static development and a widening gap between the North and the South (cited in Awojobi, 2014). 
Furthermore, just as is the case in economic loss, the social costs are significant. School enrollment that had been low or non-existent became worse with the abduction of over 250 female students by Boko Haram, in April, 2014, after they attacked their school. The sect has also attacked churches, mosques, hospital, markets, recreational places, thereby jeopardizing people's security and hampering social integration. In the area of integration, Nigerian graduates from domestic and foreign institutions now decline posting to the northeast in particular and the northern states generally fearing that their lives would be insecure. This means the aims and objectives of the National Youth Service Corps (NYSC) scheme which was originally established by the regime of General Yakubu Gowon in the 1970s, to foster unity and peace (through perhaps inter-cultural marriages, and cultural exchanges) have been defeated. This claim was authenticated by NYSC Directorate, when some time ago it posted 4171 Corps members to Adamawa, but only 3130 accepted the posting, while the rest 1041 abandoned theirs citing as reason the volatile security situation in that region (Awojobi, 2014).

In a related situation, Ovaga (n.d) asserted that Boko Haram had succeeded in disintegrating Nigerians by its campaign of terror; instilling fear and hatred among indigenes and settlers in the northeast. Using Adamawa as an example, Ovaga argued that the State which used to be home to all, Christians and Muslims, and other religious adherents, has since the advent of Boko Haram insurgency created divisions among these people. The situation has degenerated to affect the entire northern states to the point where northern parents now fear to send their wards to schools in the north; instead they send them to the southern states for their education. Ovaga (n.d) pointed out that the prevalent atmosphere in the country where the south and north trade allegations against each other for the emergence of and the escalating attacks of Boko Haram, threatened the corporate existence of Nigeria's sovereignty. For example, Southerners ab initio accused the northern elites and politicians of creating Boko Haram to truncate or frustrate the erstwhile Goodluck Jonathan's government.

However, it is the view of this paper that, whatever might be the case, is obvious to everybody today that Boko Haram is out to destabilize not only the northeast and northern Nigeria by extension, but the entire Nigerian Federation. As Kyari Mohammed (cited in Quartz Africa, 2015) has argued concerning the Boko Haram sect "they neither have the knowledge nor the power to enforce sharia. So what is their objective? To make our lives abnormal. And they have succeeded". Dauda (2014) observed that the social challenges caused by Boko Haram insurgency for northern Nigeria led to the mass movement of people out of the northeastern areas of the country, mostly Damaturu, in Yobe State.

\section{Responding to the Insurgency}

The Federal Government of Nigeria using different measures had attempted to counter the Boko Haram insurgency in the Northeast and to prevent it from spreading to the north and the rest of the country. It employed both soft (dialogue) and hard (military) tactics to quell the insurgency but to no avail as the terror attacks have continued unabated. 


\section{Soft Approach}

Soft approach in the context of Boko Haram suggests a situation when and where the insurgents were invited to dialogue with government representatives to negotiate both party's demands and interests. However, evidences to the contrary have shown that Boko Haram was illdisposed to negotiate with the Nigerian State, since it rejected the offer on several occasions. The refusal might be explained by the following (i) conferring sense of legitimacy on their adversary; (ii) fearful of being perceived as weak by their members, their adversary (the government), and by the public; (iii) fear of providing false hope to the Boko Haram constituency and government; (iv) meeting is time consuming; $(\mathrm{v}$ ) lack of confidence in the process accentuated by previous disappointments; (vi) fear of locking themselves into a tight position, etc (Agbebaku, Odion, and Edokpa, 2014). Consequently, the federal government was left with no option but to militarily confront the Boko Haram insurgents by adopting the hard tactics.

\section{Hard Approach}

Military counter-insurgency had been and is still being adopted by the federal government of Nigeria to address the Boko Haram insurgency in the northeast of the country. The exercise otherwise known as Joint Task Force (JTF) comprises all the security agencies in Nigeria, working together day and night to help bring the insurgency to an end. The exercise received a boost when President Commander-in-Chief, Muhammadu Buhari, decided on coming into office in 2015, to move the Military Command and Operations to Maiduguri, the epic centre of the insurgency. The exercise was said to have recorded some successes and failures. Some of the gains included taking over all the territories or Local Government Area that were formerly under Boko Haram, and, recently, the retake of the Sambisa forest (Quartz Africa, 2015). The losses were seen in terms of the number of arrests, tortures, killings, and detentions.

The hard approach, according to Kalyvas is a strong military response towards Boko Haram which could turn into indiscriminate violence (cited in Knoechelmann, 2014). This is evident in the many arrests, tortures, detentions, and extrajudicial killings carried out the JTF mainly in Borno State. Amnesty International and the Human Rights Watch had severally mentioned this in their reports; and the authorities had done little or nothing about it. Solomon (2012) argued that the counterterrorism efforts had yield no results in view of the continuous violence meted out by the security forces. He reported "The Joint Military Task Force (JTF) in Borno State, for instance, has resorted to unlawful killings, dragnet arrests, and extortion and intimidation of hapless residents of Borno. On one occasion, the JTF searched homes in the Kaleri Ngomari Custain area in Maiduguri, killed twenty five people, and tortured women and children (Solomon, 2012).

\section{Conclusion}

This paper examined the implications of the Boko Haram insurgency on integration in northeast, and northern Nigeria as a whole by analysing the works of previous scholars and other publications. The findings revealed that the Boko Haram insurgency has had severe security implications for the northern states' economy and political stability as well as social life generally. The study has contributed to the ongoing debate on the implications of Boko Haram Insurgency, particularly in terms of integrating people from both the northern and southern parts of Nigeria. This 
was evident in such areas as education, culture, commerce and social life. Other writers including this author have attributed the Boko insurgency in the northeast and it ramifications in northern Nigeria to the inability of government to improve the welfare of the youth who remain predominantly poor, illiterate, ignorant and unemployed and without focus. This was as typified by the relative deprivation theory which was applied to this study to argue that the northern peoples feeling of lack and their frustration, served as impetus for supporting and, in certain cases, joining the Boko Haram sect to perpetrate mayhem on hapless Nigerians living in the northeast.

\section{Recommendations}

In light of the above analysis, and based on the theoretical explanation, the paper recommends that the soft (carrot) approach should be explored further to stem the tide of Boko Haram rampaging attacks in the entire northern Nigeria. This becomes necessary judging by the inability of the military to effectively combat the Boko Haram insurgency. Specifically this study recommends that the federal governments should grant amnesty to some of the repentant members of Boko Haram. It should offer meaningful and sustainable employment to the educated ones whilst the illiterates amongst them could be helped to acquire certain skills, such as tailoring, carpentry, automobile mechanic, welding, mobile handset repair, etc., after which they could be given soft loans without interest or collateral to set up their own business and become self-employed in the process. To ensure that the down-ward trend on integration resulting from the insurgents' activities is reversed, there should be continuous youth sensitization programs on the negative consequences of joining Boko Haram group, by both government and non-governmental bodies. This could be done through the National Youth Serve Corps (NYSC) scheme. As long run measure, however, the federal and state governments should deliberately look into the lingering socio-economic plight of the north especially in terms of education and employment with a view to curbing the Boko Haram insurgency and stemming the general tide of violent conflicts in the area.

\section{References}

Agbebaku, P. E., Odion, W. E., \& Edokpa, M. (2014). Tackling Nigeria's Security Challenges: Negotiation with Boko Haram, or What? Journal of Global Initiatives, 9 (2), 69-80. Retrieved From http://digitalcommons.kennesaw.edu/cgi/viewcontent.cgi ?article=1174\&context=jgi/.

Agbiboa, D. E. (2013). Why Boko Haram Exists: The Relative Deprivation Perspective. African Conflict and Peacebuilding Review, 3(1). Retrieved from http://www.jstor.org/stable/10.2979/africonfpeacrevi.3.1.144.

Adibe, J. (2013). What Do We Really Know About Boko Haram? In Mantzikos, I. (Ed.), Boko Haram: Anatomy of a Crisis. Pp. 9-15. Bristol, UK: e-International Relations. Retrieved from http://www.eir.info/wp-content/uploads/Boko-Haram-e-IR.pdf.

Akinbi, J. O. (2015). Examining the Boko Haram Insurgency in Northern Nigeria and the Quest for Permanent Resolution of the Crisis.Global Journal of Arts, Humanities and Social Sciences, 3(8), 32 - 
INTERNATIONAL JOURNAL OF ACADEMIC RESEARCH IN BUSINESS AND SOCIAL SCIENCES Vol. 9, No. 2, Feb, 2019, E-ISSN: 2222-6990 C 2019 HRMARS

45. Retrieved from http://www.eajournals.org/wp-content/uploads/Examining-the-Boko-HaramInsurgency-in-Northern-Nigeria-and-the-Quest-for-A-Permanent-Resolution-Of-The-Crisis.pdf.

AOAV \& NWGAV (2013 December, 12). The Violent Road: Nigeria's North East. Retrieved from https://aoav.org.uk/2013/the-violent-road-nigeria-north-east/.

Aro, O. I. (2013). Boko Haram Insurgency in Nigeria: Its Implications and Way Forward Toward Avoidance of Future Insurgency. International Journal of Scientific and Research Publications, 3(11). Retrieved https://pdfs.semanticscholar.org/f1c7/5181f28aceac9823959454fe6912a9d1033a.pdf.

Awojobi, O. N. (2014). The Socio-Economic Implications of Boko Haram Insurgency in the North-East of Nigeria. International Journal of Innovation and Scientific Research, 11(1), 144-150.

Ayegba, U. S. (2015). Unemployment and Poverty as Sources and Consequence of Insecurity in Nigeria: The Boko Haram Insurgency Revisited. African Journal of Political Science and International Relations, 9(3), 90-99.

Barna, J. (2014). Insecurity in Context: The Rise of Boko Haram in Nigeria. In-depth Analyis, Directorate-General For External Policies, Policy Department, 13 July, 2014.

Dauda, M. (2014). The Effect of Boko Haram Crisis on Socioeconomic Activities in Yobe State. International Journal of Social Sciences and Humanities Invention, 1(4), 251-257.

De Silva, S. (n.d). How Does Relative Deprivation Theory Apply to the Boko Haram - Nigeria Conflict? Retrieved from https://www.academia.edu/334569/.

Ebonyi, A. A. (2018). Religious Conflict as a Threat to Nigeria's Internal Security. International Journal of Novel Research in Humanity and Social Sciences, 5(6), 137-145.

Harnischfeger, J. (2014). Boko Haram and Its Muslim Critics: Observations from Yobe State. In De Montclos, M. P. (Ed.) Boko Haram: Islamism, Politics, Security and the State in Nigeria. pp. 33-62. Leiden: African Studies Centre.

John, L \& Jock, Y (1993). Relative Deprivation. Retrieved October 16, 2017 from http://www.malcolmread.com/JockYoung/relative.htm.

Knoechelmann, M. (2014). Why the Nigerian Counter-Terrorism Policy Towards Boko Haram has Failed. International Institute for Counter-Terrorism (ICT), Working Paper 32, October, 2014. 
INTERNATIONAL JOURNAL OF ACADEMIC RESEARCH IN BUSINESS AND SOCIAL SCIENCES

Vol. 9, No. 2, Feb, 2019, E-ISSN: 2222-6990 C 2019 HRMARS

Mohammed, K. (2014). What is Boko Haram? Some Evidence and a Lot of Confusion. In De Montclos, M. P. (ed.) Boko Haram: Islamism, Politics, Security and the State in Nigeria. Pp. 9-32. Leiden: African Studies Centre.

National Bureau of Statistics (2012). The Nigeria poverty profile 2010 report. Retrieved from https://reliefweb.int/report/nigeria/nigeria-poverty-profile-2010-report

Othman, M. F., Sule, I. Z. O. \& Singh, R. S (2015). An Analysis of the Impact of Boko Haram Insurgents on Business Entrepreneurship Environment in Nigeria. Academic Journal of Interdisciplinary Studies, 4(3), http://dx.doi:10.5901/ajis.2015.v4n3p37

Ovaga, O. H. (n.d). The Socio-Economic Implications of Boko-Haram Activities in Northern Nigeria. Review of Public Administration \& Management 1(2).

Solomon, H. (2012). Counter-Terrorism in Nigeria.The RUSI Journal, 157 (4), 6-11.

Tukur, S. (2017, February). "Shocking Revelations: 100,000 killed, two million displaced by Boko Haram Insurgency, Borno Governor Says." Premium Times.

Vybiralova, L. (2016). Nigeria and Boko Haram Insurgence: The Roots of Political Violence. Causes of Political Violence (MVZ489). Retrieved from https://is.muni.cz/el/1423/jaro2016/MVZ489/61907258/Essay.pdf.

Walker, A. (2012). What is Boko Haram? United States Institute of Peace, Special Report. Retrieved from www.usip.org. 